\title{
The macrofauna of a stony sand area in the German Bight (North Sea)
}

\author{
S. Kühne \& E. Rachor \\ Alfred-Wegener-Institut für Polar- und Meeresforschung (AWI); D-27515 Bremerhaven, \\ Germany
}

\begin{abstract}
The sublittoral macrofauna of the Steingrund, a stony area east-northeast of Helgoland, was investigated from May till October 1991 using a van Veen grab and a small dredge. The diverse endo- and epifauna of the sandy bottoms, pebbles and boulders of this Saalian end moraine comprised 289 taxa, whereby the polychaetes Magelona papillicornis, Lanice conchilega and Spiophanes bombyx dominated in terms of abundance. Species rare in the German Bight, such as the sponge Leucandra fistulosa, the sea urchin Echinus esculentus, and the sea anemone Haliplanella lineata, were also found. The two sample sets were processed separately with multivariate techniques, and differentiated on the basis of occurrence and numbers of the abundant species. The analysis of the grab samples revealed two types of the Tellina-fabula-community. These associations were differentiated by the presence of species of the coarse-sand-inhabiting Goniadella-Spisulacommunity and were related to the distribution of the grain size of the sediment. Likewise, two epifaunal assemblages were distinguished. Sandy bottoms were characterized by Ophiura albida, Liocarcinus holsatus and Pagurus bernhardus, while boulders and pebbles were covered by a varied sessile and mobile epifauna dominated by the sessile bryozoan Flustra foliacea and the mobile pantopode Aechelia echinata. Numerical density, biomass and annual production estimates are in the range of values determined for the macrobenthos of the German Bight, while annual P/B ratios mounted up to 5 .
\end{abstract}

\section{INTRODUCTION}

The composition, structure and distribution of sublittoral macrobenthic communities in the German Bight were investigated by Blegvad (1922), Hagmeier (1925), Caspers (1939), Stripp (1969), Dörjes (1977), Salzwedel et al. (1985) and others. All of these surveys dealt with communities living in soft bottoms. However, little is known about the macrobenthic communities of the sublittoral, hard substrata in the southeastern North Sea (Caspers, 1950; Dörjes, 1977). The scarcity of these substrata in the German Bight (Fig. 1) is one reason for this; the difficulty in obtaining quantitative samples is another. The majority of these substrata are regarded as residues of the end moraines of Saalian and Weichselian stages of the Glacial Period (Pratje, 1951).

The structural heterogeneity and the physical resistence of these hard substrata impede a comprehensive quantitative sampling of sessile and mobile macrobenthos. Even Janke (1986), whose macrobenthic investigations were limited to the rocky intertidal zone of Helgoland, faced these problems. Lüning (1970) and de Kluijver (1991) used SCUBA diving as a suitable method, while the investigations of Caspers (1950) and Dörjes (1977) were based on grab samples. 


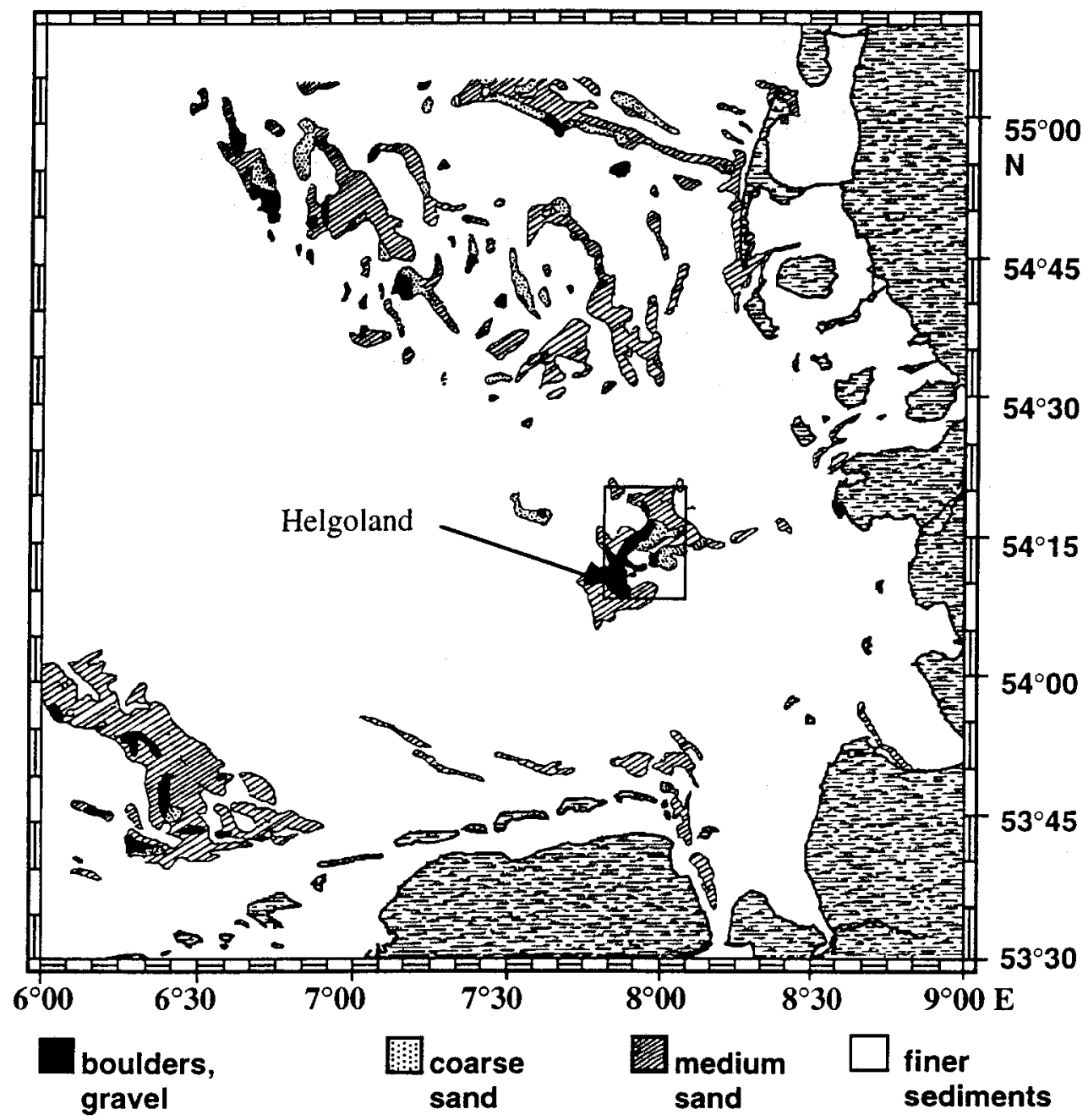

Fig. 1. Distribution of the sandy and rocky deposits in the German Bight with the area of investigation (framed) near Helgoland (after Figge, 1981)

This synecological study of the sessile and mobile macrobenthos at the Steingrund near Helgoland is based on an investigation of Kühne (1992), who combined two different sampling techniques (using van Veen grabs and a dredge).

\section{MATERIAL AND METHODS}

\section{Area of investigation}

The Steingrund, literally stony ground, is the remains of a Saalian end moraine, about $11 \mathrm{~km}$ east-northeast of Helgoland. The study area (Fig. 2) stretches from the 


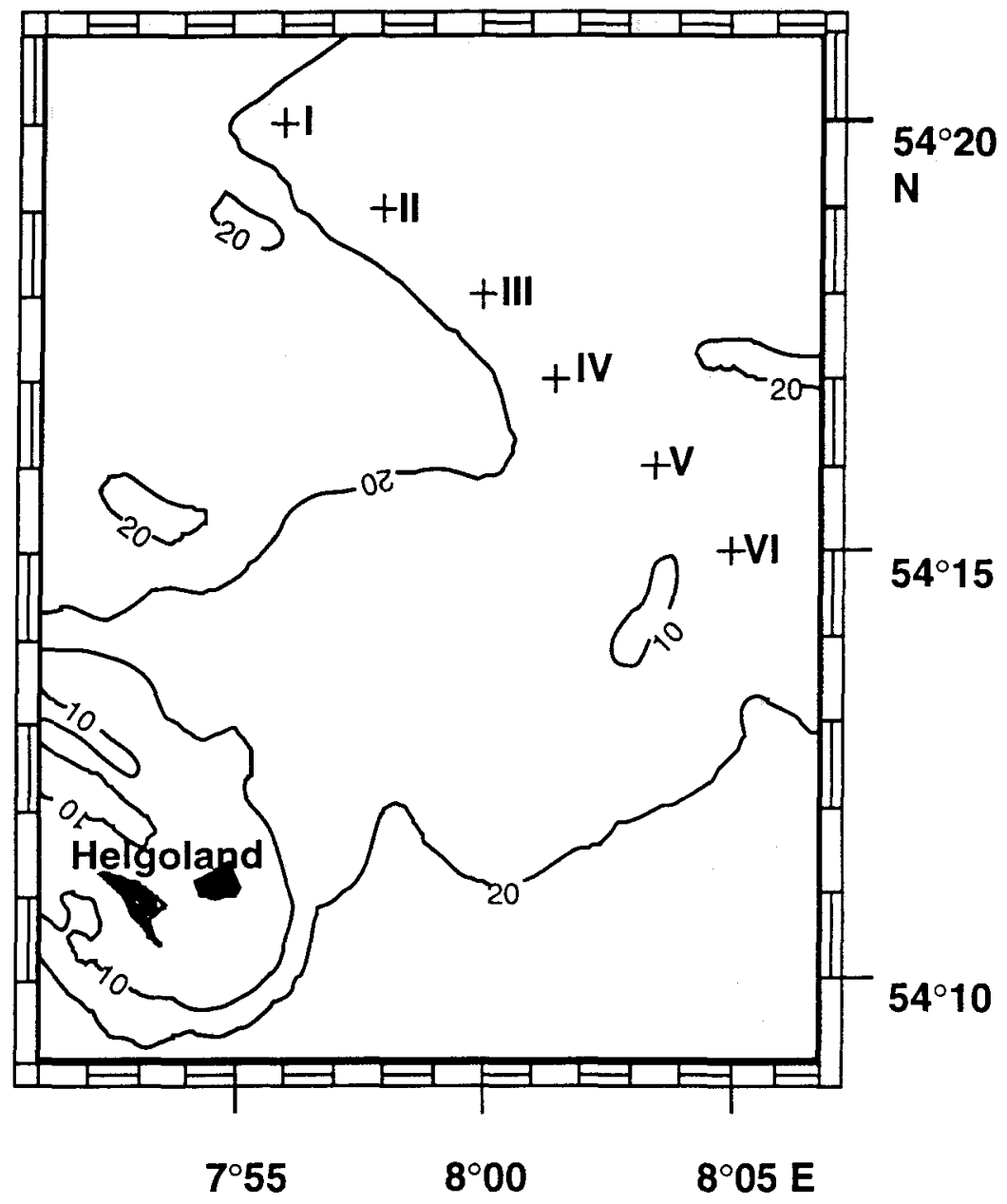

Fig. 2. Investigation area northeast of Helgoland, with the stations I to VI in the Steingrund

northwestern border of Steingrund to its highest parts at the buoy "Tonne Steingrund" $\left(54^{\circ} 14^{\prime} \mathrm{N}, 8^{\circ} 05.5^{\prime} \mathrm{E}\right)$.

Water depths varied between 8 and $22 \mathrm{~m}$, and water temperatures in the area are quite uniform, changing seasonally $\left(2-19^{\circ} \mathrm{C}\right)$. Variations in salinity, between 30 and 33 $\%$, are caused by the fluctuating estuarine water inflow from the river Elbe. Nevertheless, this area can be considered as not heavily polluted. Strong tidal currents with a mean velocity of $0.6 \mathrm{kt}$ allow almost saturated concentrations of dissolved oxygen of about 8-10 $\mathrm{mg} / \mathrm{l}$ in the bottom waters.

The sediment consists mainly of medium to coarse sands, locally intermixed with boulders and pebbles (Schulz, 1983). 


\section{Sampling and sample treatment}

The macrofauna of the Steingrund was investigated during three cruises with the RV "Victor Hensen" of the AWI Bremerhaven. Infauna samples were taken with a van Veen grab $\left(0.1 \mathrm{~m}^{2}\right)$ at six stations (I-VI, Fig. 2) in May, August and October 1991. These samples were separately sieved on $1-\mathrm{mm}$ screens and preserved in $5 \%$ formalin buffered with hexamethylene-tetramine for further laboratory analysis.

In addition, 15 hauls were made with a small frame dredge $11 \mathrm{~m}$ width, $1 \mathrm{~cm}$ mesh size), each trawl covering an area of about $900 \mathrm{~m}^{2}$. These samples were sorted and the fauna determined on board.

Moreover, supplementary information was gained from some larger grab samples and by visual observations during diving.

The animals were counted and identified to species level as far as possible. Total wet weights were measured separately for the following 5 groups: polychaetes, molluscs, crustaceans, echinoderms and all remaining taxa ("miscellaneous"). Larger animals, such as the heart urchin Echinocardium cordatum, were weighed individually. The wet weights were converted into ash-free dry weights using the comparably high conversion factors 0.2 for polychaetes, crustaceans and miscellaneous $(0.1$ for the tunicate Molgula sp.) and 0.07 for molluscs and echinoderms (Thorson, 1957; Rumohr et al., 1987; Atkins \& Wacasey, 1976; cf. also Salzwedel et al., 1985).

\section{Data processing}

Simpson's diversity index (Simpson, 1949) and Heip's evenness (Heip, 1974) were calculated. K-dominance curves were drawn to compare diversities and dominances of different clusters (see Lambshead et al., 1983).

The van Veen grab and the dredge samples, 2 sample sets representing the different sampling techniques and the 3 sampling dates, were processed separately. These sample sets were subjected to analyses by three different multivariate techniques: (1) an agglomerative, hierarchical clustering method, using unweighted pair-groups method with arithmetic averages (UPGMA), (2) a divisive, hierarchical classification method, named the two-way indicator-species analysis (TWINSPAN), and (3) a correspondence analysis (CA; or reciprocal averaging). These techniques are described in detail by Hill (1979), ter Braak (1987) and Piepenburg (1988).

Bryozoans and hydroids as well as the anthozoan Alcyonium digitatum were omitted in these computer analyses. The classification and ordination of the dredge samples were based on the ranked data of 144 taxa.

Characterizing species were identified in order to describe and differentiate benthic associations according to the method of Salzwedel et al. (1985). A species is considered characteristic of a station group when it fulfills at least three of the following conditions:

- numerical dominance within the association is more than $5 \%$

- presence within the association is more than $66 \%$

- the number of individuals of the species concerned within the association divided by the total number of individuals of that species found in the whole study area (DAI) is more than $0.66(66 \%)$

- the number of stations within the association at which the species occurred divided 
by the total number of stations at which the species occurred (DAS) is more than $0.66(66 \%)$

For the determination of epibenthic associations (rank data), the degree of association regarding individuals (DAI) was replaced by the degree of association regarding ranks (DAR).

\section{RESULTS}

\section{Bottom deposits}

The substrata of the area were very heterogeneous. They varied from boulders and stones (station I) to medium sand (station VI), and were locally intermixed with fine sand (station III). The general gradient in grain size from south to north is superimposed by a strong patchiness of stones and boulders. In some areas, pebbles and boulders were intermixed with small amounts of coarse sand. The hard substrata were covered by the bryozoans Flustra foliacea and Alcyonidium sp., the anthozoans Alcyonium digitatum and Metridium senile and other sedentary animals.

\section{Species composition}

In total, 289 different taxa were found, comprising 75 Crustacea, 73 Annelida, 50 Mollusca, 32 Coelenterata, 23 Chordata, 12 Echinodermata, 7 Bryozoa and 17 others (Table 1). Species that are rare in the German Bight (cf. "Red List": Rachor et al., 1995), for example the sponge Leucandra fistulosa, the anthozoan Haliplanella lineata and the edible sea urchin Echinus esculentus, were also found. In addition, a few individuals of the rare flatfishes Arnoglossus laterna (station group 2) and Phrynorhombus laterna (station group 1) were collected by the dredges. According to Fricke (1987), they accidentally migrate from the north into the German Bight.

\section{Station groups and associations}

Multivariate analyses of grab and dredge samples, comprising only the "noncolonial" taxa, produced two station groups (Figs 3,4,5): group 1 including stations I and II and group 2 all other stations (III to VI).

This clustering was consistent in both sample sets (grabs and dredges) on all sampling dates (May, August and October). It is correlated with the composition of the sediment, in that group 2 comprises the sites with medium to coarse sands, and station group 1 those with boulders and pebbles.

The position of sample IIIMa in the ordination plot (Fig. 6) suggests that this sample shares characteristic species of both clusters. Depending on the multivariate technique used, this sample is classified either in group 1 or 2.

The macrofauna of the two station groups differ in the composition, number, abundance and biomass of the species (Fig. 7), and are subsequently taken as specific associations. 
Table 1. List of species found in the Steingrund (" indicates "Red List" species; see text)

\begin{tabular}{|c|c|c|}
\hline Species & Species & Species \\
\hline \multirow[t]{2}{*}{ CHORDATA } & ECHINOIDEA & Hippomedon denticulatus \\
\hline & Echinocardium cordatum & (Bate) \\
\hline VERTEBRATA & (Pennant) & Jassa falcata (Mont.) \\
\hline Agonus cataphractus (Linné) & Echinocyamus pusillus & Lembos websteri Bate \\
\hline Ammodytes aff. tobianus L. & (O. F. Müller) • & Megaluropus agilis Hoek \\
\hline \multirow{2}{*}{$\begin{array}{l}\text { Arnoglossus laterna } \\
\text { (Walbaum) }\end{array}$} & Echinus esculentus L." & Metopa alderi (Bate) \\
\hline & Psammechinus miliaris & Microprotopus maculatus \\
\hline Buglossidium luteum (Risso) & (Gmelin)* & Norman \\
\hline Callionymus juv. & & Orochomene nana (Kröyer) \\
\hline \multirow{2}{*}{$\begin{array}{l}\text { Callionymus reticulatus } \\
\text { Valenciennes }\end{array}$} & BRYOZOA & Parapleustes bicuspis (Kröyer) \\
\hline & Alcyonidium aff. gelati- & Perioculodes longimanus (Bate \\
\hline \multirow{2}{*}{$\begin{array}{l}\text { Ctenolabrus rupestris (L.) } \\
\text { Gadus morhua L. }\end{array}$} & nosum (L.) & \& Westwood) \\
\hline & Bugula aff. flabellata (Thoms.) & Photis longicaudata (Bate \& \\
\hline Gobiidae indet. spp. & Conopeum reticulum (L.) & Westwood) \\
\hline \multirow{2}{*}{$\begin{array}{l}\text { Hyperoplus lanceolatus } \\
\text { (Le Sauvage) }\end{array}$} & Crisia eburnea (L.) & Photis reinhardi Kröyer \\
\hline & Electra pilosa (L.) & Phoxocephalus holbolli \\
\hline \multirow{2}{*}{$\begin{array}{l}\text { Limanda limanda (L.) } \\
\text { Liparis aff. liparis (L.) }\end{array}$} & Flustra foliacea (L.) & (Kröyer) ${ }^{*}$ \\
\hline & Scrupocellariasp. & Pontocratus arenarius (Bate) \\
\hline \multirow{2}{*}{$\begin{array}{l}\text { Merlangius merlangus (L.) } \\
\text { Microstomus kitt (Walbaum) }\end{array}$} & CRUSTACEA & Stenula rubrovittata (Sars) \\
\hline & & Synchelidium haplocheles \\
\hline Myoxocephalus scorpius (L.) & AMPHIPODA & (Sars) \\
\hline \multirow{3}{*}{$\begin{array}{l}\text { Pholis gunnellus (L.) } \\
\text { Phrynorhombus norvegicus } \\
\quad \text { (Günther) }\end{array}$} & Ampelisca brevicornis (Costa) & Urothoe poseidonis Reibisch \\
\hline & Ampelisca diadema (Costa) & \\
\hline & Ampelisca spinipes Boeck & ISOPODA \\
\hline Platichthys flesus (L.) & Ampelisca sp. & Janira maculosa Leach* \\
\hline \multirow{2}{*}{$\begin{array}{l}\text { Pleuronectes platessa L. } \\
\text { Solea solea Ouensel }\end{array}$} & Ampelisca tenuicornis & \\
\hline & Lilljeborg & CUMACEA \\
\hline \multirow{2}{*}{$\begin{array}{l}\text { Syngnathus acus } \mathrm{L} . \\
\text { Trachurus trachurus (L.) }\end{array}$} & Amphilochus sp. & Bodotria scorpioides \\
\hline & Amphipoda juv. & (Mont.) \\
\hline \multirow[b]{2}{*}{ ACRANIA } & Amphithoe rubricata & Diastyloides biplicata (Sars) \\
\hline & (Montagu) & Diastylis bradyi Norman \\
\hline \multirow{2}{*}{$\begin{array}{l}\text { Branchiostoma lanceolatum } \\
\quad \text { Pallas }\end{array}$} & Aora typica Kröyer & Diastylis cornuta (Boeck) \\
\hline & Argissa hamatipes (Norman) & Iphinoe trispinosa (Goods.) \\
\hline \multirow{2}{*}{ ECHINODERMATA } & Atylus falcatus Metzger & Lamprops fasciata Sars \\
\hline & Atylus swammerdami & Pseudocuma similis G. O. Sars \\
\hline ASTEROIDEA & (Milne-Edwards) & \\
\hline \multirow[t]{2}{*}{ Asterias rubens L. } & Bathyporeia elegans Watkin & DECAPODA \\
\hline & Bathyporeia guilliamsoniana & Brachyura larvae \\
\hline \multirow{2}{*}{$\begin{array}{l}\text { OPHIUROIDEA } \\
\text { Acrocnida brachiata } \\
\text { (Montagu) }\end{array}$} & (Bate) & Cancer pagurus L. \\
\hline & $\begin{array}{l}\text { Bathyporeia gracilis Sars } \\
\text { Bathyporeia pelagica (Bate) }\end{array}$ & $\begin{array}{l}\text { Corystes cassivelaunus } \\
\text { (Pennant) }\end{array}$ \\
\hline \multirow{2}{*}{$\begin{array}{l}\text { Amphipholis squamata Delle } \\
\text { Chiaje* }\end{array}$} & Caprella linearis (L.)* & Crangon allmanni Kinshan \\
\hline & Corophium crassicorne & Crangon crangon (L.) \\
\hline \multirow{2}{*}{$\begin{array}{l}\text { Amphiura filiformis } \\
\text { (O. F. Müller) }^{*}\end{array}$} & Bruzelius & Crangon juv. \\
\hline & Corophium sextonae Crawford & Eualus pusiolus (Kröyer) \\
\hline \multirow{2}{*}{$\begin{array}{l}\text { Ophiothrix fragilis } \\
\text { (Abildgaard)* }\end{array}$} & Corophium juv. & Galathea intermedia Lilljeborg \\
\hline & Gammaropsis maculata & Galathea strigosa (L.)* \\
\hline Ophiura albida Forbes & (Johnston) & Hyas araneus (L.) \\
\hline Ophiura ophiura (L.) & Gammaropsis nitida & Liocarcinus holsatus \\
\hline Ophiuridae juv. & (Stimpson) & (Fabrizius) \\
\hline
\end{tabular}


Table 1 (continued)

\begin{tabular}{|c|c|c|}
\hline Species & Species & Species \\
\hline DECAPODA & Eteone longa (Fabricius) & Sabellaria spinulosa Leuckart" \\
\hline Liocarcinus pusillus (Leach)* & Eteonesp. & Scalibregma inflatum (Rathke) \\
\hline Macropodia rostrata (L.) & Eulalia bilineata (Johnston) & Scolelepis (S.) bonnieri (Mesnil) \\
\hline Maja squinado (Herbst) & Eulalia viridis (L.) & Scoloplos armiger \\
\hline Pagurus bernhardus (L.) & Eumida sanguinea (Oersted) & (O. F. Müller) \\
\hline $\begin{array}{l}\text { Pandalina brevirostris } \\
\text { (Rathke) }\end{array}$ & $\begin{array}{l}\text { Eusyllis blomstrandi } \\
\text { Malmgren }\end{array}$ & $\begin{array}{l}\text { Sphaerodorum flavum } \\
\text { (Rathke) }\end{array}$ \\
\hline Pandalus montagui Leach & Flabelligera affinis M. Sars & Spio armata (Thulin) \\
\hline Pilumnus hirtellus (L.) & Gattyana cirrosa (Pallas) & Spio filicornis (Müller) \\
\hline Pinnotheres pisum (L.) ${ }^{*}$ & Glycera capitata Oersted * & Spio goniocephala Thulin \\
\hline Pisidia longicornis (L.) ${ }^{*}$ & Glycera rouxii Audouin \& & Spiophanes bombyx \\
\hline Thia scutellata (Fabricius) ${ }^{\circ}$ & Milne-Edw. & (Claparede) \\
\hline Thoralus aff. cranchii (Leach) & $\begin{array}{l}\text { Glycinde nordmanni } \\
\text { (Malmgren) }\end{array}$ & $\begin{array}{l}\text { Sthenelais limicola (Ehlers) } \\
\text { Syllides longocirrata Oersted }\end{array}$ \\
\hline CIRRIPEDIA & Goniada maculata Oersted & Syllis gracilis Grube \\
\hline $\begin{array}{l}\text { Balanus balanoides }(\mathrm{L} .) \\
\text { Balanus sp. }\end{array}$ & $\begin{array}{l}\text { Goniadella bobretzkii } \\
\text { (Annenkova) }\end{array}$ & $\begin{array}{l}\text { Thelepus cincinnatus } \\
\text { (Fabricius) }\end{array}$ \\
\hline $\begin{array}{l}\text { Verruca stroemia } \\
\text { (O. F. Müller) }\end{array}$ & $\begin{array}{l}\text { Harmothoe (H.) impar } \\
\text { (Johnston) } \\
\text { Lanice conchilega (Pallas) }\end{array}$ & $\begin{array}{l}\text { Travisia forbesi Johnston } \\
\text { Polychaeta indet spp. }\end{array}$ \\
\hline $\begin{array}{l}\text { COPEPODA } \\
\text { Copepoda indet spp. }\end{array}$ & $\begin{array}{l}\text { Lepidonotus squamatus (L.)* } \\
\text { Magelona alleni Wilson }\end{array}$ & MOLLUSCA \\
\hline Harpacticoidea indet spp. & Magelona papillicornis & CEPHALOPODA \\
\hline ANNELIDA & $\begin{array}{l}\text { F. Müller } \\
\text { Nephtys caeca (Fabricius) }\end{array}$ & Decabrachia spp. \\
\hline HIRUDINEA & Nephtys cirrosa Ehlers & LAMELLIBRANCHIATA \\
\hline Calobdella nodulifera Malm & $\begin{array}{l}\text { Nephtys hombergi Savigny } \\
\text { Nepthys longosetosa Oersted }\end{array}$ & $\begin{array}{l}\text { Abra alba (Wood) } \\
\text { Abra nitida (Müller) }\end{array}$ \\
\hline OLIGOCHAETA & Nereis pelagica L." & Angulus donacinus (L.) \\
\hline Oligochaeta indet. spp. & $\begin{array}{l}\text { Nicolea zostericola (Oersted) } \\
\text { Ophelia limacina (Rathke) }\end{array}$ & $\begin{array}{l}\text { Arctica islandica (L.) } \\
\text { Astarte triangularis (Montagu) }\end{array}$ \\
\hline POLYCHAETA & Ophelina acuminata Oersted & Cardium edule $\mathrm{L}$. \\
\hline $\begin{array}{l}\text { Ampharete finmarchica } \\
\text { (M. Sars) }\end{array}$ & $\begin{array}{l}\text { Orbinia (O.) sertulata } \\
\text { (Savigny) }\end{array}$ & $\begin{array}{l}\text { Cochlodesma praetenue } \\
\text { (Pulteney) }\end{array}$ \\
\hline $\begin{array}{l}\text { Anaitides groenlandica } \\
\text { (Oersted) }\end{array}$ & $\begin{array}{l}\text { Owenia fusiformis Chiaje } \\
\text { Pectinaria koreni Malmgren }\end{array}$ & $\begin{array}{l}\text { Corbula gibba (Olivi)* } \\
\text { Cultellus pellucidus (Pennant) }\end{array}$ \\
\hline Anaitides aff. maculata (L.) & Pholöe minuta (Fabricius) & Donax vittatus (da Costa) \\
\hline Anaitides mucosa (Oerstedt) & Phyllodocidae juv. & Dosinia exoleta (L.) \\
\hline Anaitides subulifera Eliason & Pisione remota (Southern) & Ensis siliqua L. \\
\hline Aonides paucibranchiata & Poecilochaetus serpens Allen & Ensis sp. \\
\hline Southern & Polycirrus medusa Grube & Hiatella rugosa (L.) \\
\hline Autolytus prolifer (Müller) & Polycirrus sp. & Mactra corallina Montagu \\
\hline Capitella capitata (Fabricius) & Polydora antennata & Modiolus aff. barbatus (L.) \\
\hline Chaetozone setosa Malmgren & Claparede & Modiolus modiolus L.* \\
\hline $\begin{array}{l}\text { Chone infundibuliformis } \\
\text { Kröyer }\end{array}$ & $\begin{array}{l}\text { Polydora caeca (Oersted) } \\
\text { Polydora pulchra (Carazzi) }\end{array}$ & $\begin{array}{l}\text { Montacuta bidentata } \\
\text { (Montagu) }\end{array}$ \\
\hline $\begin{array}{l}\text { Cossura longocirrata } \\
\text { Webster \& Benedict }\end{array}$ & $\begin{array}{l}\text { Polygordius spec. } \\
\text { Pomatoceros triqueter (L.) }\end{array}$ & $\begin{array}{l}\text { Montacuta ferruginosa } \\
\text { (Montagu) }\end{array}$ \\
\hline $\begin{array}{l}\text { Eteone barbata (Malmgren) } \\
\text { Eteone flava (Fabricius) }\end{array}$ & $\begin{array}{l}\text { Protodorvillea kefersteini } \\
\text { (McIntosh) }\end{array}$ & $\begin{array}{l}\text { Mya arenaria L. } \\
\text { Nucula nitidosa Winckworth }\end{array}$ \\
\hline
\end{tabular}


Table 1 (continued)

\begin{tabular}{|c|c|c|}
\hline Species & Species & Species \\
\hline LAMELLIBRANCHIATA & Nassarius incrassatus (Ström) ${ }^{*}$ & Laomedea sp. \\
\hline Spisula solida L." & Polycera quadrilineata & Metridium senile L. * \\
\hline Spisula subtruncata da Costa ${ }^{*}$ & (Müller) & Perigonium cirratus Hartlaub \\
\hline Tellina fabula Gronovius & Tritonia plebeia Johnston & Plumularia setacea (L.) \\
\hline Tellina tenuis da Costa* & Tritonia sp. & Polymorpha spp. \\
\hline $\begin{array}{l}\text { Thracia villosiuscula } \\
\text { (Macgillivray) }\end{array}$ & COELENTERATA & $\begin{array}{l}\text { Sagartia troglodytes Price } \\
\text { Scyphozoa indet. spp. }\end{array}$ \\
\hline $\begin{array}{l}\text { Venerupis pullastra } \\
\text { (Montagu)" }\end{array}$ & $\begin{array}{l}\text { ACNIDARIA } \\
\text { Pleurobrachia pileus Müller } \\
\text { Ctenophora indet spp. }\end{array}$ & $\begin{array}{l}\text { Sertularella rugosa }(\mathrm{L} .) \\
\text { Sertularia cupressina } \mathrm{L} .{ }^{-} \\
\text {Sertularia tenera } \mathrm{G} \text { O Sars }\end{array}$ \\
\hline & CNIDARIA & Tealia felina L. \\
\hline GASTROPODA & Abietinaria abietina (L.) & Tubularia spp. \\
\hline Acanthodoris pilosa (Müller) & Alcyonium digitatum $\mathrm{L} .{ }^{*}$ & \\
\hline Aeolidia papillosa (L.)* & Anthozoa sp. & \\
\hline Antiopella sp. & Calicella syringa (L.) & MISCELLANEOUS \\
\hline Buccinum undatum $\mathrm{L} .{ }^{*}$ & Campanularia aff. johnstoni & Molgula sp. \\
\hline Coryphella spp. & Adler & Chaetognatha indet spp. \\
\hline $\begin{array}{l}\text { Cuthona concinna } \\
\text { (Alder \& Hancock) }\end{array}$ & $\begin{array}{l}\text { Cerianthus lloydii Gosse } \\
\text { Corymorpha sp." }\end{array}$ & 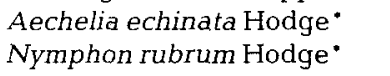 \\
\hline Cuthona gymnota & Diphasia rosacea (L.) & Golfingia sp. \\
\hline $\begin{array}{l}\text { Dendronotus frondosus } \\
\text { (Ascanius) }\end{array}$ & $\begin{array}{l}\text { Edwardsia sp. } \\
\text { Eudendrium sp. }\end{array}$ & $\begin{array}{l}\text { Sipunculidae indet spp. } \\
\text { Phoronis sp. }\end{array}$ \\
\hline Doris sp. & Halecium halecinum (L.) & Cryptocelis alba \\
\hline Doto coronata (Gmelin) & Haliplanella lineata (Verrill) ${ }^{\bullet}$ & Polycladidae indet spp. \\
\hline $\begin{array}{l}\text { Eubranchus exiguus (Alder \& } \\
\text { Hancock) }\end{array}$ & $\begin{array}{l}\text { Hydractinia echinata Fleming } \\
\text { Hydrallmania falcata (L.)" }\end{array}$ & $\begin{array}{l}\text { Nemertines indet. spp. } \\
\text { Oncholaimus sp. }\end{array}$ \\
\hline Eubranchus sp. & Laomedea conferta Hartlaub & Nematodes indet spp. \\
\hline Gibbula cineraria L. & Laomedea dichotoma (L.) & Cliona lobata Hancock \\
\hline Hydrobia ulvae Pennant. & Laomedea geniculata (L.) & Cliona sp." \\
\hline Limacia clavigera (Müller) & Laomedea neglecta Alder & Leucandra fistulosa \\
\hline Lunatia catena da Costa & Laomedea pelagica & (Johnston) * \\
\hline Lunatia nitida Donovan & (van Breemen) & Porifera indet sp. \\
\hline
\end{tabular}

\section{Grab samples}

All the grab samples showed some similarities in species composition, but, according to the station clusters, also distinct differences. The main average structural association data are presented in Tables 2 and 3 and in Figure 7.

\section{Station group 1}

The association structure of the fauna of stations I and II is related to their substrate and habitat heterogeneity, created by the intermixture of coarse sand with boulders and pebbles. Accordingly, the total species number of 116 was larger than in the other station group. 18 of all identified species (Table 1) were solely found in the grab samples of station group 1. Among them, only Scalibregma inflatum, Protodorvillea kefersteini, Corophium sextonae and Doris sp. occurred in more than two samples and are therefore 


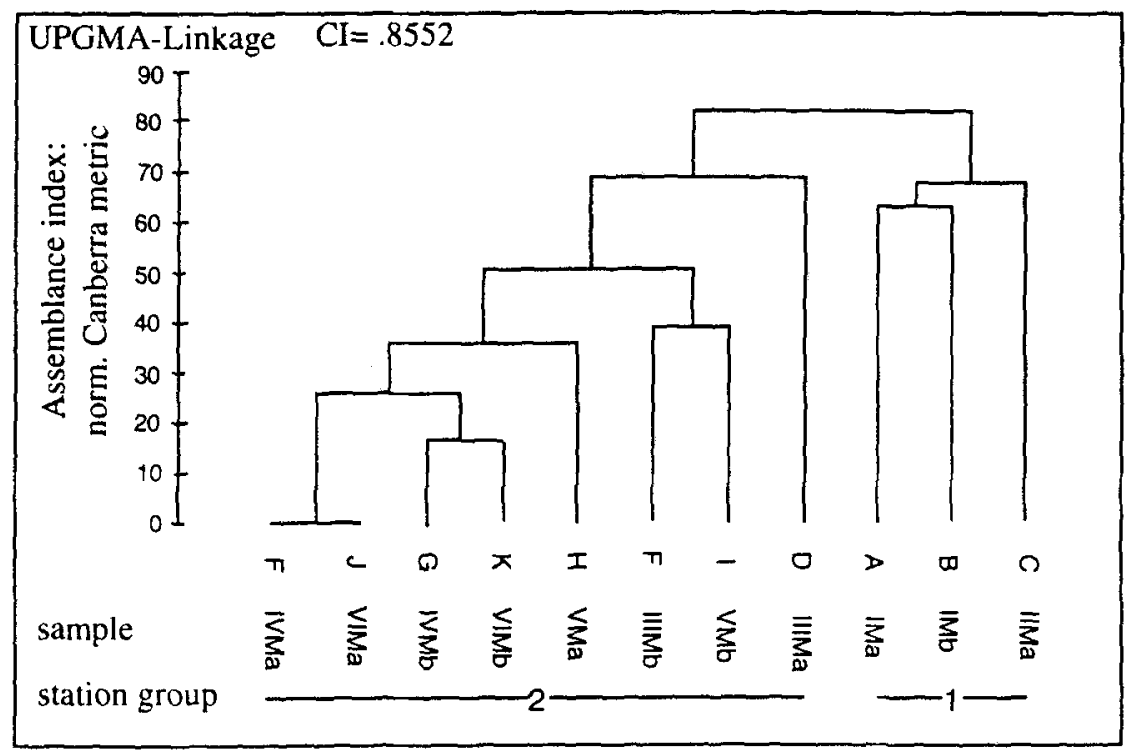

Fig. 3. Dendrogram of the hierarchical classification (COMM-Program) of the grab samples of May $(\mathrm{Ma}, \mathrm{Mb}=$ single grabs, obtained at the different locations indicated by the numbers I-VI)

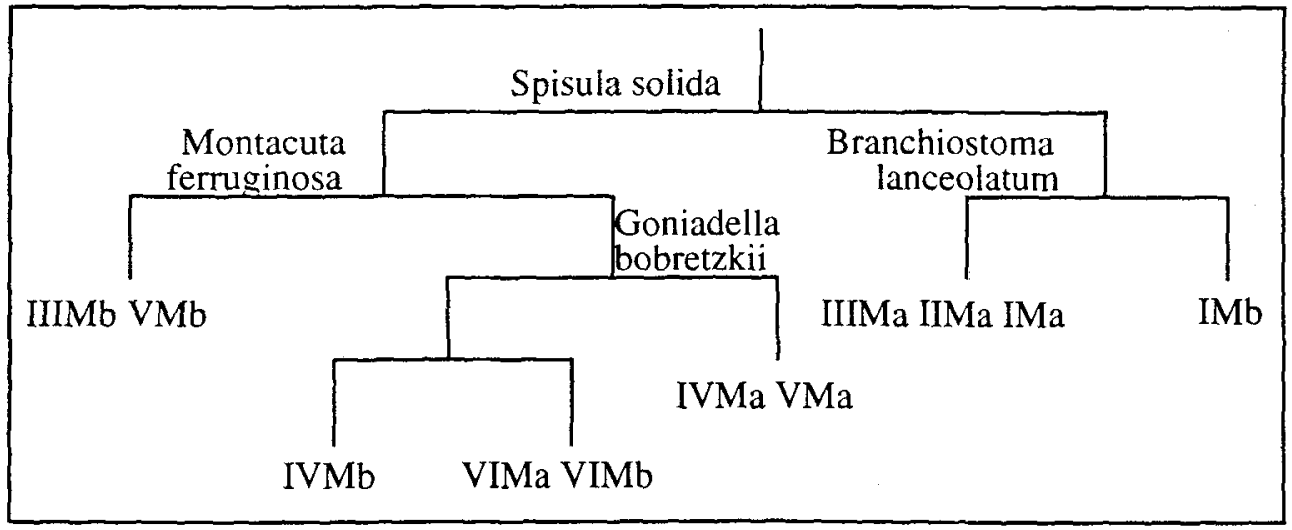

Fig. 4. Dendrogram of the divisive classification (TWINSPAN) of the May subsamples (grab). The main divisions are marked by an "indicator species" and its group affiliation (site of occurrence). For further explanations, see Fig. 3

considered as specific for this association. Epibenthic species such as the polycladid Cryptocelis alba, the crustaceans Pilumnus hirtellus and Thia scutellata, the balanid Verruca stroemia, the sponge Cliona sp. and the brittle star Ophiotrix fragilis were also found only in this association. Fifteen species of bryozoans (e.g. Flustra foliacea) and hydroids (e.g. Sertularella rugosa) were present.

The characterizing species was the polychaete Anaitides mucosa. Together with 


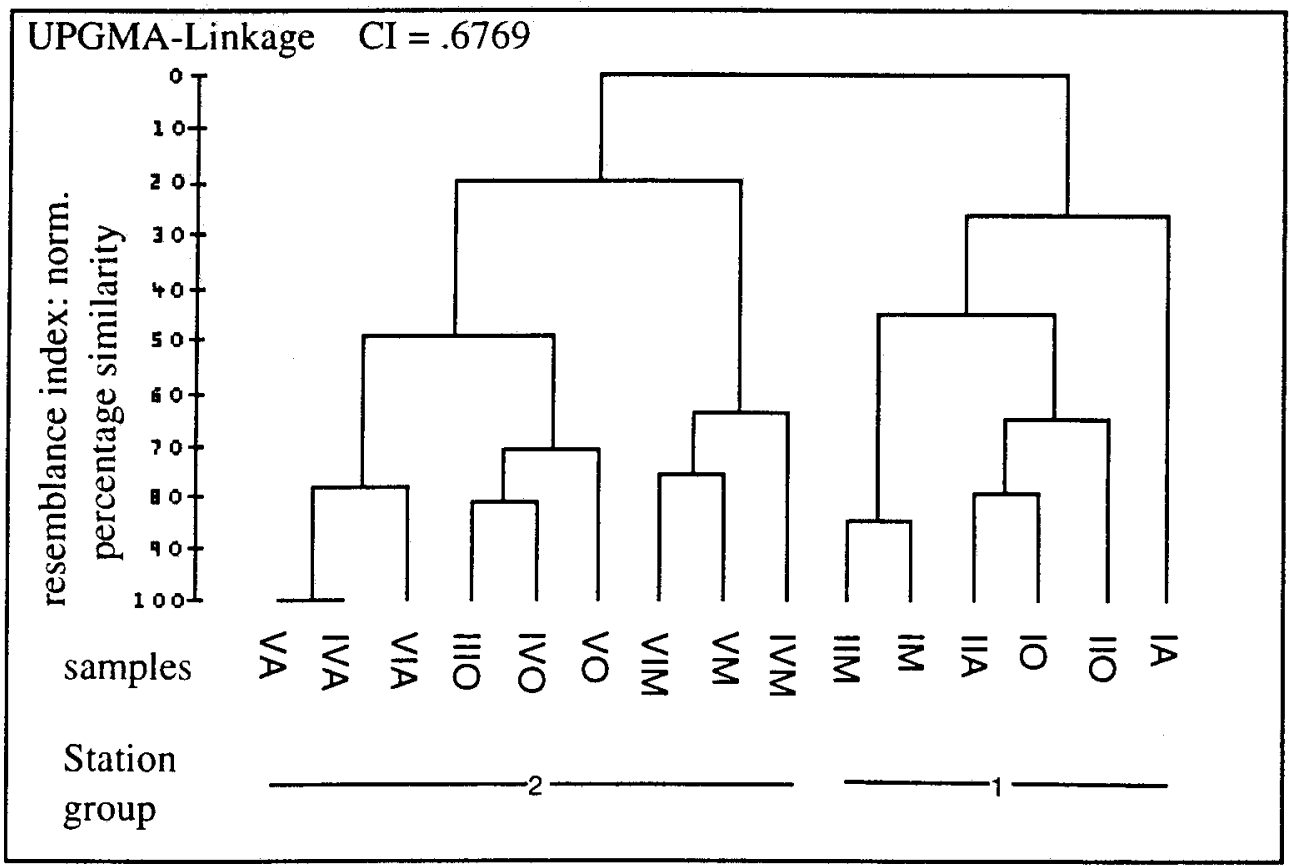

Fig. 5. Dendrogram of the hierarchical classification (COMM-Program) of the dredge subsamples $($ May $=M$, August $=A$, October $=O)$. The data were not transformed. For further explanations, see Fig. 3

Lanice conchilega it contributed $38.8 \%$ to the total number of individuals found in this association (Table 3 ).

The mean numbers of individuals and the mean biomass (ash-free dry weights) are much lower than in group 2 (Fig. 7). In spite of this, the highest number of individuals and the maximum species numbers in single samples were found in group 1. Especially in August, extreme densities of Lanice conchilega $\left(6620 \mathrm{ind} . / \mathrm{m}^{2}\right)$ and Anaitides mucosa $\left(7100\right.$ ind. $\left./ \mathrm{m}^{2}\right)$ were recorded. Altogether, the polychaetes dominated with regard to numerical abundance and the number of species.

\section{Station group 2}

108 species were found in the medium to coarse sands at stations III to VI; and, according to Simpson's index, the association of group 2 was less diverse than that of group 1 (Table 2).

The association is characterized by the polychaetes Magelona papillicornis, Spiophanes bombyx, Nephtys cirrosa, and the bivalve Spisula solida. M. papillicornis and $S$. bombyx accounted for more than $60 \%$ of all individuals found (Table 3). 16 species, for example the bivalves Astarte triangularis, Montacuta ferruginosa, Thracia villosciusculus and Ensis siliqua, the amphipod Bathyporeia guilliamsoniana and the polychaete Anaitides subulifera were specific for this association.

The echinoderms Acrocnida brachiata, Amphiura filiformis and Echinocyamus pusil- 


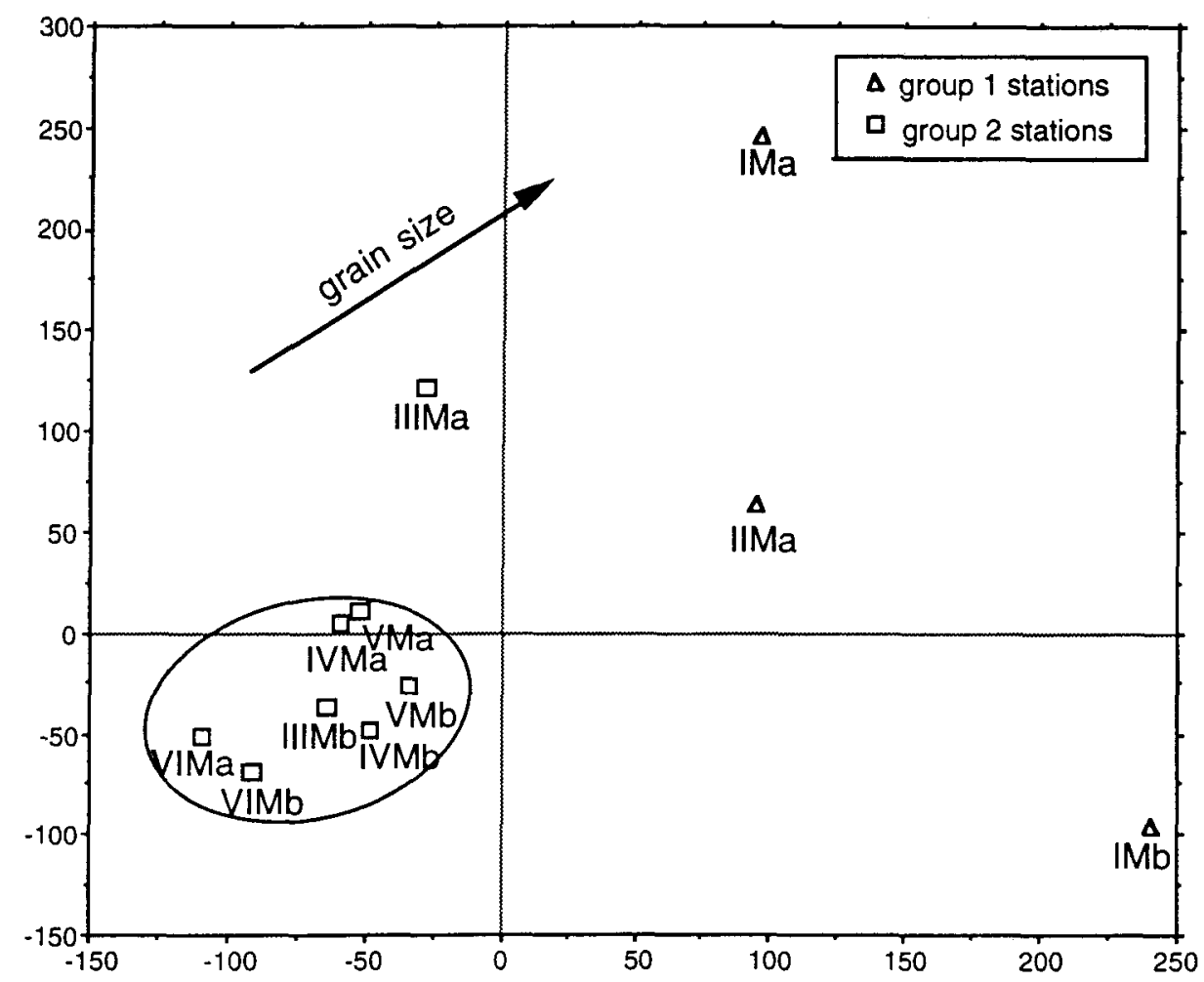

Fig. 6. Canonical community ordination (CANOCO) of the May subsamples (grabs) correlated to the grain size increasing towards sample IMa. For further explanations, see Fig. 3

lus, the crustaceans Pontocrates arenarius, Jassa falcata, Synchelidium haplocheles and Pandalina brevirostris and the polychaetes Chaetozone setosa, Flabelligera affinis and Poecilochaetus serpens occurred, in low numbers, only in this association. A few epibenthic species like the nudibranch Eubranchus exiguus and the echinoderm Ophiura ophiura were also found.

While mean numbers of species were almost equal, numerical abundances and mean biomasses were generally higher than in association 1, except in August (Fig. 7). The overall maximum biomass $\left(182.4 \mathrm{~g} / \mathrm{m}^{2}\right)$ was found at station IV in August.

\section{Dredge samples}

The ranked data of the dredge samples did not allow the same analytical treatment as the abundance data of the grab samples. Nevertheless, these macrofauna samples were divided into the same two station groups as the grab samples, with two different associations (Fig. 5) according to their species composition. 

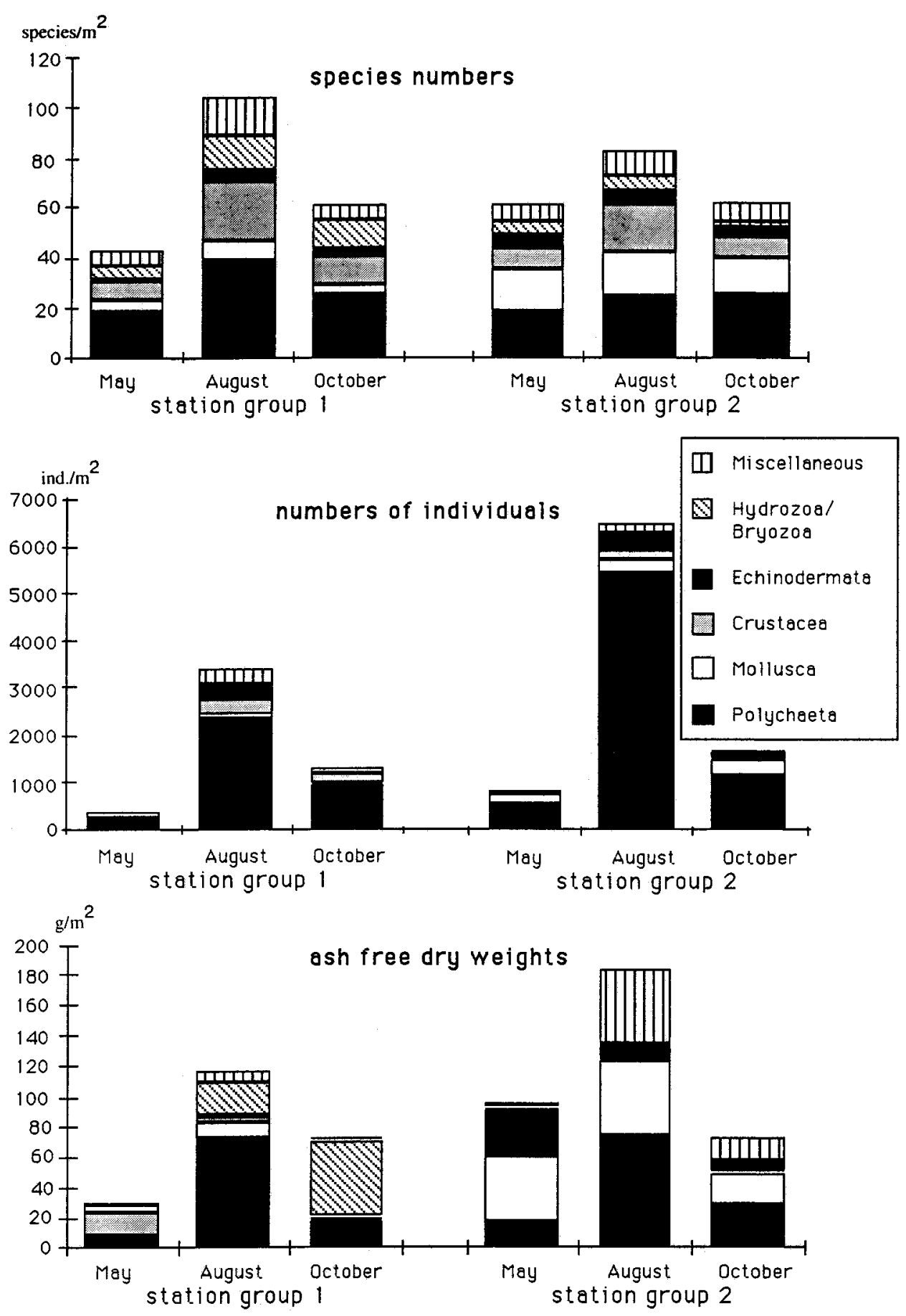

Fig. 7. Numbers of species and individuals and biomass (ash-free dry weight) of the grab samples 
Table 2. Species numbers, diversity, evenness and the names of the dominant species for each station group, sample set and date

\begin{tabular}{|c|c|c|c|c|c|c|}
\hline & $\begin{array}{l}\text { Station } \\
\text { group }\end{array}$ & $\begin{array}{l}\text { Species } \\
\text { number }\end{array}$ & $\begin{array}{l}\text { Spec. number } \\
(90 \% \text { of indiv.) }\end{array}$ & $\begin{array}{l}\text { Dominant } \\
\text { species }\end{array}$ & $\begin{array}{l}\text { Simpson's } \\
\text { index }\end{array}$ & $\begin{array}{l}\text { Heip's } \\
\text { evenness }\end{array}$ \\
\hline \multicolumn{7}{|c|}{ van Veen grab } \\
\hline \multirow[t]{2}{*}{ May } & 1 & 39 & 20 & Aonides paucibranchiata & 0.92 & 0.493 \\
\hline & 2 & 56 & 23 & Aonides paucibranchiata & 0.92 & 0.356 \\
\hline \multirow[t]{2}{*}{ August } & 1 & 92 & 26 & Lanice conchilega & 0.837 & 0.18 \\
\hline & 2 & 77 & 12 & Magelona papillicornis & 0.661 & 0.077 \\
\hline \multirow[t]{2}{*}{ October } & 1 & 50 & 21 & Anaitides mucosa & 0.854 & 0.264 \\
\hline & 2 & 60 & 14 & Magelona papillicornis & 0.705 & 0.126 \\
\hline \multicolumn{7}{|l|}{ Dredge } \\
\hline \multirow[t]{2}{*}{ May } & 1 & 43 & 35 & Eusyllis blomstrandi & 0.964 & 0.784 \\
\hline & 2 & 28 & 23 & Ophiura albida & 0.933 & 0.696 \\
\hline \multirow[t]{2}{*}{ August } & 1 & 41 & 36 & Aora typica & 0.969 & 0.894 \\
\hline & 2 & 63 & 47 & Liocarcinus holsatus & 0.977 & 0.802 \\
\hline \multirow[t]{2}{*}{ October } & 1 & 59 & 47 & Eusyllis blomstrandi & 0.975 & 0.812 \\
\hline & 2 & 46 & 36 & Ophiura albida & 0.961 & 0.725 \\
\hline
\end{tabular}

\section{Station group 1}

The macrozoobenthos association of this station group is more diverse than that of group 2 (see Table 2 and Fig. 9), with the exception of the August samples. $65 \%$ of the 124 epibenthic species found in all the dredge samples are present in this association, 16 species being restricted to it. 17 were also found in the grab samples of this station group.

The mean number of species in this association was larger than in association 2 . The summation of the ranks (classes of abundance) shows the same trend. The crustaceans dominated by the numbers of species and individuals. The pantopode Aechelia echinata and the polychaete Eusyllis blomstrandi were identified as the characteristic species (Table 4). However, they were not restricted to this station group, as were the polychaete Pomatocerus triqueter and the crustacean Pandalus montagui. Although the bryozoan Flustra foliacea was present in several dredges (seen also during diving) and is to be regarded typical for the area, a quantification and ranking was not possible and, accordingly, no further analytical treatment.

\section{Station group 2}

The ophiurid Ophiura albida, the bivalve Spisula solida and the crustacean Liocarcinus holsatus were the characteristic species.

14 species of 91 in total were restricted to this association; but, only the sandeel Ammodytes tobianus belonged to the 20 dominants (Table 4). The bivalves Angulus donacinus, Astarte triangularis and Thracia villosciusculus, the other sandeel Hyperoplus lanceolatus and the polychaete Nephtys longosetosa were typical, but of very low incidence. Spisula solida, the hermit crab Pagurus bernhardus, and Ophiura albida had a presence of $100 \%$, but they were not restricted to the association. 
Table 3. List of the 20 dominant species found in the grab samples from the two station groups.

- Characterizing species; " typical species (presence $100 \%$ ); POL = Polychaeta; CHO = Chordata; $\mathrm{CRU}=$ Crustacea $;$ VER $=$ Vertebrata $; \mathrm{ECH}=$ Echinodermata $; \mathrm{ANT}=$ Anthozoa; $\mathrm{MOL}=\mathrm{Mollusca}$

\begin{tabular}{|c|c|c|c|c|c|c|}
\hline $\begin{array}{l}\text { VanVeen } \\
\text { STATION GROUP } 1\end{array}$ & Class. & $\begin{array}{l}\text { Number of indiv. } \\
\left.\text { [ind. } / \mathrm{m}^{2}\right]\end{array}$ & $\begin{array}{c}\text { Dominance } \\
\qquad[\%]\end{array}$ & $\begin{array}{l}\text { Presence } \\
{[\%]}\end{array}$ & $\begin{array}{l}\text { DAS } \\
{[\%]}\end{array}$ & $\begin{array}{l}\text { DAI } \\
{[\%]}\end{array}$ \\
\hline Lanice conchilega & POL & 593 & 27.96 & 53.85 & 28.00 & 70.54 \\
\hline Anaitides mucosa & POL & 230 & 10.84 & 69.23 & 45.00 & 72.57 \\
\hline Aonides paucibranchiata & POL & 172 & 8.09 & 76.92 & 35.71 & 53.22 \\
\hline Ophiuridae juv. & $\mathrm{ECH}$ & 115 & 5.44 & 61.54 & 29.63 & 38.86 \\
\hline Aora typica & CRU & 77 & 3.63 & 53.85 & 87.50 & 99.01 \\
\hline Pectinaria koreni & POL & 62 & 2.90 & 38.46 & 55.56 & 85.11 \\
\hline Gattyana cirrosa** & POL & 55 & 2.57 & 46.15 & 100.00 & 100.00 \\
\hline Glycera capitata & POL & 45 & 2.14 & 53.85 & 70.00 & 81.94 \\
\hline Sabellaria spinulosa & POL & 42 & 1.96 & 38.46 & 83.33 & 94.74 \\
\hline Cerianthus lloydi & ANT & 41 & 1.92 & 46.15 & 54.55 & 82.81 \\
\hline Liocarcinus holsatus & CRU & 38 & 1.81 & 38.46 & 50.00 & 78.13 \\
\hline Eumida sanguinea & POL & 37 & 1.74 & 38.46 & 41.67 & 30.97 \\
\hline Nemertines & & 37 & 1.74 & 69.23 & 40.91 & 53.93 \\
\hline Goniadella bobretzkii & POL & 27 & 1.27 & 76.92 & 50.00 & 17.07 \\
\hline Pomatoceros triqueter & POL & 26 & 1.23 & 23.08 & 75.00 & 87.18 \\
\hline Anthozoa sp. & ANT & 26 & 1.23 & 38.46 & 55.56 & 82.93 \\
\hline Scoloplos armiger & POL & 24 & 1.12 & 46.15 & 40.00 & 65.96 \\
\hline Mya arenaria & MOL & 22 & 1.02 & 38.46 & 83.33 & 96.55 \\
\hline Abra alba & MOL & 20 & 0.94 & 38.46 & 41.67 & 59.09 \\
\hline Protodorvillea kefersteini* & POL & 20 & 0.94 & 46.15 & 100.00 & 100.00 \\
\hline \multicolumn{7}{|l|}{ STATION GROUP 2} \\
\hline Magelona papillicornis * & POL & 1546 & 51.34 & 70.83 & 99.65 & 73.91 \\
\hline Spiophanes bombyx* & POL & 286 & 9.49 & 87.50 & 99.28 & 84.00 \\
\hline Lanice conchilega & POL & 134 & 4.46 & 75.00 & 29.46 & 72.00 \\
\hline Ophiuridae juv. & $\mathrm{ECH}$ & 98 & 3.27 & 79.17 & 61.14 & 70.37 \\
\hline Tellina fabula & MOL & 97 & 3.21 & 58.33 & 99.15 & 93.33 \\
\hline Astarte triangularis * * & MOL & 87 & 2.88 & 37.50 & 100.00 & 100.00 \\
\hline Aonides paucibranchiata & POL & 82 & 2.71 & 75.00 & 46.78 & 64.29 \\
\hline Goniadella bobretzkii & POL & 71 & 2.35 & 41.67 & 82.93 & 50.00 \\
\hline Nephtys cirrosa* & POL & 59 & 1.95 & 95.83 & 88.68 & 82.14 \\
\hline Anaitides mucosa & POL & 47 & 1.56 & 45.83 & 27.43 & 55.00 \\
\hline Echinocardium cordatum & $\mathrm{ECH}$ & 46 & 1.54 & 54.17 & 83.46 & 72.22 \\
\hline Eumida sanguinea & POL & 45 & 1.48 & 29.17 & 69.03 & 58.33 \\
\hline Euphausidae & CRU & 35 & 1.16 & 45.83 & 93.33 & 78.57 \\
\hline Spio filicornis & POL & 32 & 1.05 & 54.17 & 98.70 & 92.86 \\
\hline Edwardsia sp. & ANT & 29 & 0.95 & 41.67 & 84.15 & 62.50 \\
\hline Ophelia limacina & POL & 28 & 0.94 & 62.50 & 73.12 & 71.43 \\
\hline Spisula solida* & $\mathrm{MOL}$ & 20 & 0.65 & 70.83 & 94.00 & 85.00 \\
\hline Nemertines & & 17 & 0.57 & 54.17 & 46.07 & 59.09 \\
\hline Branchiostoma lanceolatus & $\mathrm{CHO}$ & 15 & 0,48 & 37.50 & 61.40 & 56.25 \\
\hline Donax vittatus & MOL & 14 & 0.46 & 41.67 & 94.29 & 90.91 \\
\hline
\end{tabular}

\section{Some comments on algae}

Only drifting material of the red algae Delesseria sanguinea, Chorda filum and brown algae of the genus Laminaria were found in the dredges and in some grabs; but, 


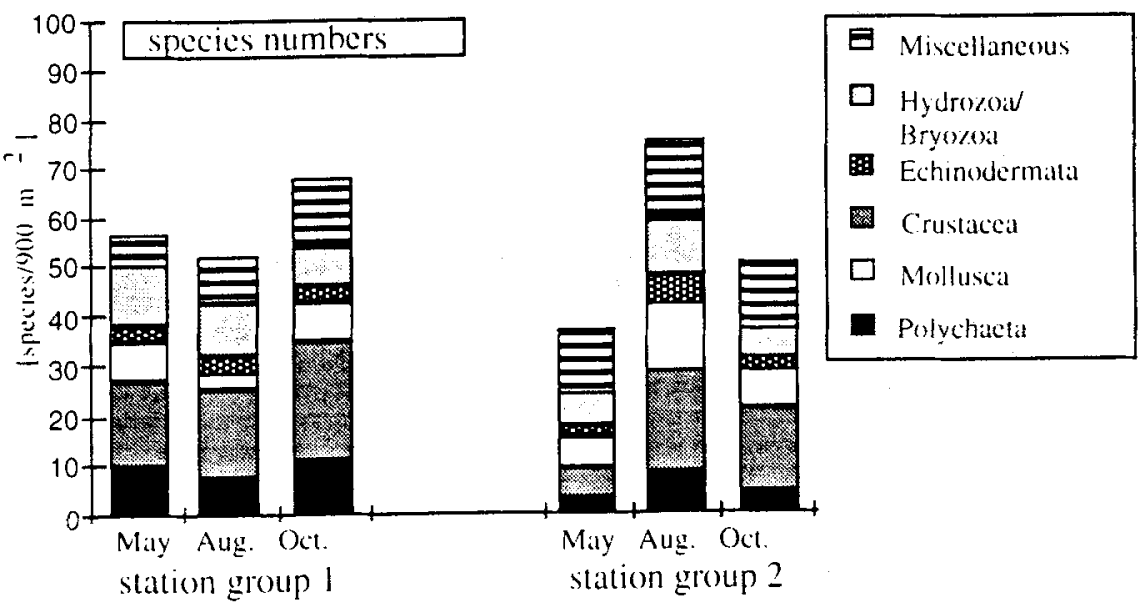

Fig. 8. Number of species in the two station groups based on all dredge sample sets (May, August, October)

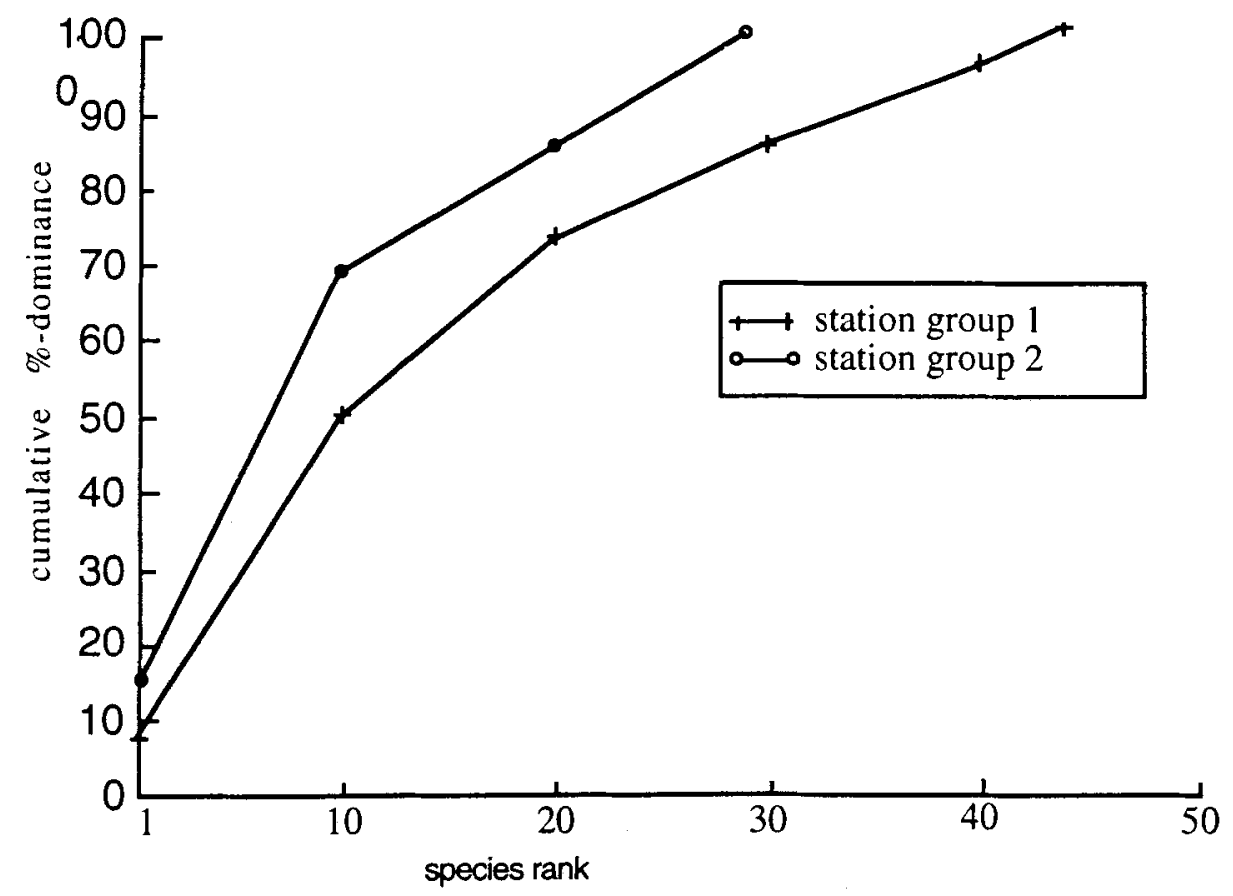

Fig. 9. Comparison of the $\mathrm{k}$-dominance curves of the two station groups (dredge samples in May) 
Table 4. List of the 20 dominant species found in the dredge samples from the two station groups.

Other explanations: see Table $3 ;$ VER $=$ Vertebrata (fish)

\begin{tabular}{|c|c|c|c|c|c|}
\hline $\begin{array}{l}\text { Dredge } \\
\text { STATION GROUP } 1\end{array}$ & Class. & $\begin{array}{c}\text { Dominance } \\
{[\%]}\end{array}$ & $\begin{array}{c}\text { Presence } \\
{[\%]}\end{array}$ & $\begin{array}{l}\text { DAS } \\
{[\%]}\end{array}$ & $\begin{array}{l}\text { DAR } \\
{[\%]}\end{array}$ \\
\hline Eusyllis blomstrandi* & POL & 6.55 & 100.00 & 90.00 & 75.00 \\
\hline Asterias rubens & $\mathrm{ECH}$ & 4.36 & 83.33 & 66.67 & 55.56 \\
\hline Metridium senile & ANT & 4.36 & 66.67 & 85.71 & 66.67 \\
\hline Crangon allmanni & CRU & 3.64 & 83.33 & 45.45 & 45.45 \\
\hline Aora typica & CRU & 3.27 & 66.67 & 42.86 & 44.44 \\
\hline Aechelia echinata* & CRU & 2.55 & 83.33 & 87.50 & 83.33 \\
\hline Corophium sextonae & CRU & 2.55 & 66.67 & 77.78 & 66.67 \\
\hline Cancer pagurus & CRU & 2.18 & 66.67 & 75.00 & 66.67 \\
\hline Hyas araneus & CRU & 2.18 & 66.67 & 50.00 & 40.00 \\
\hline Pisidia longicornis & CRU & 2.18 & 50.00 & 75.00 & 75.00 \\
\hline Pomatoceros triqueter * & CRU & 2.18 & 50.00 & 100.00 & 100.00 \\
\hline Pagurus bernhardus & CRU & 1.82 & 66.67 & 27.78 & 30.77 \\
\hline Pandalus montagui" * & $\mathrm{CRU}$ & 1.82 & 66.67 & 100.00 & 100.00 \\
\hline Modiolus modiolus & MOL & 1.82 & 50.00 & 55.56 & 75.00 \\
\hline Spisula solida & MOL & 1.82 & 33.33 & 21.74 & 18.18 \\
\hline Ophiura albida & $\mathrm{ECH}$ & 1.82 & 66.67 & 16.67 & 30.77 \\
\hline Nematodes & NET & 1.82 & 33.33 & 83.33 & 66.67 \\
\hline Gobiidae & VER & 1.45 & 50.00 & 23.53 & 33.33 \\
\hline Myoxocephalus scorpius & VER & 1.45 & 50.00 & 80.00 & 75.00 \\
\hline Crangon crangon & $\mathrm{CRU}$ & 1.45 & 33.33 & 26.67 & 28.57 \\
\hline \multicolumn{6}{|l|}{ STATION GROUP 2} \\
\hline Ophiura albida & $\mathrm{ECH}$ & 7.40 & 100.00 & 83.33 & 69.23 \\
\hline Spisula solida* & MOL & 5.33 & 100.00 & 78.26 & 81.82 \\
\hline Gobiidae & VER & 3.85 & 66.67 & 76.47 & 66.67 \\
\hline Pagurus bernhardus & CRU & 3.85 & 100.00 & 72.22 & 69.23 \\
\hline Aora typica & CRU & 3.55 & 55.56 & 57.14 & 55.56 \\
\hline Crangon allmanni & CRU & 3.55 & 66.67 & 54.55 & 54.55 \\
\hline Liocarcinus holsatus* & CRU & 3.55 & 77.78 & 75.00 & 77.78 \\
\hline Crangon crangon & CRU & 3.25 & 55.56 & 73.33 & 71.43 \\
\hline Callionymus reticulatus & VER & 2.66 & 66.67 & 75.00 & 75.00 \\
\hline Anthozoa spp. & ANT & 2.66 & 55.56 & 69.23 & 62.50 \\
\hline Lunatia nitida & MOL & 2.37 & 55.56 & 80.00 & 71.43 \\
\hline Balanus spp. & CRU & 2.07 & 33.33 & 77.78 & 60.00 \\
\hline Ophiura ophiura & $\mathrm{ECH}$ & 2.07 & 66.67 & 77.78 & 85.71 \\
\hline Ammodytes tobianus *" & VER & 1.78 & 44.44 & 100.00 & 100.00 \\
\hline Hyas araneus & CRU & 1.78 & 66.67 & 50.00 & 60.00 \\
\hline Asterias rubens & $\mathrm{ECH}$ & 1.78 & 44.44 & 33.33 & 44.44 \\
\hline Ophiuridae juv. & $\mathrm{ECH}$ & 1.78 & 33.33 & 85.71 & 75.00 \\
\hline Anaitides mucosa & POL & 1.78 & 44.44 & 66.67 & 66.67 \\
\hline Eumida sanguinea & POL & 1.78 & 33.33 & 85.71 & 75.00 \\
\hline Buglossidium luteum & VER & 1.48 & 44.44 & 71.43 & 80.00 \\
\hline
\end{tabular}

no seaweeds were found growing on stones at the shallowest sites of the Steingrund during diving. Only some small patches of crustose red algae were found on collected boulders; they were not identified.

The red alga Audouinella membranacea was detected in hydroids from the shallow 
areas of the Steingrund. According to Kornmann \& Sahling (1977), it lives in the chitinous walls of hydroids (e.g. Sertularella sp.).

\section{DISCUSSION}

Two main station groups (habitats) were differentiated applying multivariate techniques at the Steingrund, and each of them had a typical endofaunal association based on the van Veen grab samples as well as a distinct epifaunal association yielded by the dredge samples.

Up to five different soft-bottom macrofauna communities have been described for the German Bight (Hagmeier, 1925; Stripp, 1969; Salzwedel et al., 1985). The latter distinguished two different sand communities: the Tellina-fabula-community in fine sands and the Goniadella-Spisula-community in coarse sands. Very heterogeneous coarse sand sediments characterize the area of investigation (Steingrund) and its vicinity (Helgoländer Austernbank and Amphioxussand).

Following Salzwedel et al., the associations found in the grabs of both station groups are modifications of a Tellina-fabula-community. They have some additional and transitional stage characters: Association 1 was characterized by a large proportion of epibenthic decapods, nudibranchs, hydroids and bryozoans. Characteristic species of the Tellina-fabula-community were present (e.g. the polychaete Spiophanes bombyx), as well as typical species of the Goniadella-Spisula-community, such as Protodorvillea kefersteini. Therefore, this association is regarded as a Tellina-fabula-community, with some features of the Goniadella-Spisula-community and strong influences of a rock epifauna.

The presence of the bivalve Abra alba, an inhabitant of mud, silty sand and soft muddy gravel bottoms (Tebble, 1966), as well as species like the polychaete Pomatocerus triqueter, which is mainly found on hard substrata (Hartmann-Schröder, 1971), indicate the variability of the fauna and the sediment within this station group.

The influence of the Goniadella-Spisula-community was much stronger in the association of station group 2. Tellina fabula, which is characteristic for the Tellinafabula-community, occurred together with Spisula solida and Goniadella bobretzkii, which are characteristic for the Goniadella-Spisula-community.

These two endofaunal associations differ greatly from the other soft-bottom communities described by Hagmeier (1925), Stripp (1969) and Salzwedel et al. (1985), and also partly from the sand-inhabiting "Venus-gallina-community" of the first two authors.

The two epifaunal associations, defined by dredge sampling, were totally different in their species composition. The association of stations I and II inhabits a field of boulders and pebbles that stretches from Helgoland to the northeast (see Fig. 1). The typical epibenthic species Eusyllis blomstrandi and Aechelia echinata were identified as characteristic. Other mobile species found, like Cancer pagurus, Pilumnus hirtellus, Echinus esculentus and Pholis gunnellus, were also regarded as typical of hard bottoms (Frauenheim et al., 1989). The main predators in this animal-dominated zone seem to be crustaceans and echinoderms, which is also true of other waters (Canadian: Logan, 1988).

In addition, the sessile epibenthic species Alcyonium digitatum, Flustra foliacea and Metridium senile were found in large numbers at both stations and also in the shallower parts of the Steingrund (during diving). Especially Alcyonium and Flustra are regarded typical of the hard substrata around Helgoland (de Kluijver, 1991). 
In a comprehensive view, this Steingrund epifaunal association is to be characterized by Flustra foliacea and Aechelia echinata. But, it is not yet known whether these two species are generally typical for stony grounds in the southern North Sea, while there is some resemblance in species composition to the hard-bottom communities of the shallow sublittoral zone of the inner Hebrides (Mitchell et al., 1983).

Little is known about the densities and biomass of the macrofauna of stony sand areas in our waters. It was shown in this paper (Fig. 7) that the abundances in the Steingrund area are within the variability of the Tellina-fabula- and Goniadella-Spisulacommunities as described by Salzwedel et al. (1985). Biomass figures (of October, the same sampling time as in Salzwedel et al.) are comparable with those of the Tellinafabula-community, but - in station group 1 - not with those of the Goniadella-Spisulacommunity (about $3.7 \mathrm{~g}$ AFDW in October 1991 compared with $13 \mathrm{~g}$ in 1975). The epifauna, as a main component of the community, is not sufficiently included in these figures. Nevertheless, by comparing the minimal biomass values obtained in May with the maxima of August, an idea about the ("minimum") production (g AFDW m ${ }^{-2}$ ) can be formed by subtraction:

Group 1: Aug.-May: 23.7-4.7 $\mathrm{g}=19 \mathrm{~g} ; \mathrm{P} / \mathrm{B}_{\mathrm{M}}=5.0 ;(\mathrm{P} / \mathrm{B}=1.8)$

Group 2: Aug.-May: $19.2-8.6 \mathrm{~g}=10.6 \mathrm{~g} ; \mathrm{P} / \mathrm{B}_{\mathrm{M}}=2.2 ;(\mathrm{P} / \mathrm{B}=0.9)$

$\mathrm{P} / \mathrm{B}_{\mathrm{M}}$ ratios (based on May biomass) are high, while (annual) production and $\mathrm{P} / \mathrm{B}$ (based on average biomass) are within the variability known from the German Bight and other temperate waters (Warwick et al., 1978; Salzwedel, 1980).

The epifaunal association of station group 2 was typical of a sandy bottom community dominated by Lunatia catena. Ophiura albida and Liocarcinus holsatus were identified as the characterizing species. However, they were found in both station groups. Thus, the association of station group 2 is well differentiated only by the endobenthic bivalve Spisula solida. The occurrences of Hyas araneus, Pilumnus hirtellus, Ophiura albida, Corystes cassivelaunus, Arnoglossus laterna and Solea solea emphasized that this association is typical for the southern North Sea (Frauenheim et al., 1989).

The patchiness of the sediments is reflected by the spatial distribution of the benthos. A correlation between the benthos and the sediment was already proposed by Petersen (1913) and discussed many times (Davis, 1925; Jones, 1950; Künitzer et al., 1992). Nevertheless, the mean number of macro-infaunal species decreased towards station I and II, where boulders and gravel were intermixed with very coarse sands. On the other hand, the number of epifaunal species increased towards these stations.

The species composition of the neighbouring Helgoländer Austernbank (Caspers, 1950) and the Tiefe Rinne south of Helgoland (Caspers, 1939; Berberich, 1989) are not so similar (50-62\% of the species found there were also found at the Steingrund) as the species composition of the Borkum-Riffgrund ( $75 \%$, see Dörjes, 1977), another stony area in the German Bight north of the island of Borkum.

It must be mentioned that several of the species found in the Steingrund area are rare in the German Bight according to the "Red List" of Rachor et al. (1995), e.g. the sponge Leucandra fistulosa, the sea anemone Haliplanella lineata, the leather coral Alcyonium digitatum, and the edible sea urchin Echinus esculentus and about 40 other invertebrates, indicated in Table 1. This rarity can be explained by the scarcity of suitable hard substrates in the southeastern North Sea, the poor knowledge of their fauna, but also by the shelter provided by boulders especially from bottom trawling. As an example, the sea 
urchin Echinus esculentus was probably more common early in this century, even on soft bottoms in the German Bight and the open North Sea (Gerdes, 1976; Stein et al., 1990).

More extensive synecological studies of stony grounds within the North Sea are required, using a combination of different sampling methods including imaging and diving, before a general description can be worked out.

Acknowledgements. We thank the crew of the R.V. "Victor Hensen" for their support during sampling. Discussions with R. Federizon, C.-P. Günther, I. Kröncke (all Bremerhaven) helped to improve the draft manuscript. This is publication no. 1047 of the AWI Bremerhaven.

\section{LITERATURE CITED}

Atkins, E. G. \& Wacasey, J. W., 1976. Caloric values of zoobenthos and phytobenthos from the Canadian Arctic. - Tech. Rep. Fish. mar. Serv. 632, 1-24.

Berberich, D., 1989. Vergleichende Untersuchungen zur Artenzusammensetzung, Abundanz und Biomasse des Makrozoobenthos der Helgoländer Tiefen Rinne von 1936/37 und 1988/89. Dipl. Arb., TH Darmstadt, 142 pp.

Blegvad, H., 1922. Animal communities in the southern North Sea. - Proc. zool. Soc. Lond. 1922, $27-32$.

Caspers, H., 1939. Die Bodenfauna der Helgoländer Tiefen Rinne. - Helgoländer wiss. Meeresunters. 2, 1-112.

Caspers, H., 1950. Die Lebensgemeinschaft der Helgoländer Austernbank. - Helgoländer wiss. Meeresunters. 3, 120-169.

Davis, F. M., 1925. Quantitative studies on the fauna of the sea bottom. 2. Results of the investigations in the southern North Sea, 1921-1924. - Fish. Invest., Lond. (Ser. 2) 8, 1-50.

Dörjes, J., 1977. Über die Fauna des Borkum Riffgrundes (Nordsee). - Senckenb. marit. 9, 1-17.

Figge, K., 1981. Sedimentverteilung in der Deutschen Bucht 1:250000. Karte Nr. 2900. Dt. Hydrogr. Inst., Hamburg.

Frauenheim, K., Neumann, V., Thiel, H. \& Türkay, M., 1989. The distribution of the larger epifauna during summer and winter in the North Sea and its suitability for environmental monitoring. Senckenb. marit. 20, 101-118.

Fricke, R., 1987. Deutsche Meeresfische - Bestimmungsbuch. Dt. Jugendbund für Naturbeobachtung, Hamburg, 219 pp.

Gerdes, D., 1976. Zur Verbreitung der Echinodermen in der Deutschen Bucht. Dipl. Arb., Univ. Kiel, $46 \mathrm{pp}$.

Hagmeier, A., 1925. Vorläufiger Bericht über die vorbereitenden Untersuchungen der Bodenfauna der Deutschen Bucht mit dem Petersen-Bodengreifer. - Ber. dt. wiss. Kommn Meeresforsch 1, $247-272$.

Hartmann-Schröder, G., 1971. Annelida, Borstenwürmer, Polychaeta. - Tierw. Dtl. 58, 1-594.

Heip, C., 1974. A new index measuring evenness. - J. mar. biol. Ass. U.K. 54, 555-557.

Hill, M. O., 1979. TWINSPAN - a FORTRAN program for arranging multivariate data in an ordered two-way table by classification of individuals and attributes. Cornell University, Ithaca, N. Y.s $90 \mathrm{pp}$.

Janke, K., 1986. Die Makrofauna und ihre Verteilung im Nordost-Felswatt von Helgoland. Helgoländer Meeresunters. 40, 1-55.

Jones, N. S., 1950. Marine bottom communities. - Biol. Rev. 25, 283-313.

Kluijver, M. J., de, 1991. Sublittoral hard substrate communities off Helgoland. - Helgoländer Meeresunters. 45, 317-344.

Kornmann, P. \& Sahling, P.-H., 1977. Meeresalgen von Helgoland. - Helgoländer wiss. Meeresunters. $29,1-289$.

Kühne, S., 1992. Die Fauna des Steingrundes in der Deutschen Bucht. Dipl. Arb., Univ. Bonn, $127 \mathrm{pp}$.

Künitzer, A., Basford, D., Craeymeersch, J. A., Dewarumez, J.-M., Dörjes, J., Duineveld, G. C. A., Eleftheriou, A., Heip, C., Herman, P., Kingston, P., Niermann, U., Rachor, E., Rumohr, H. \& de 
Wilde, P. A. J., 1992. The benthic infauna of the North Sea: species distribution and assemblages. - ICES J. mar. Sci. 49, 127-143.

Lambshead, P. J. D., Platt, H. M. \& Shaw, K. M., 1983. The detection of differences among assemblages of dominance and diversity. - J. nat. Hist. 17, 859-874.

Logan, A., 1988. A sublittoral hard-substrata epibenthic community below $30 \mathrm{~m}$ in Head Harbour Passage, New Brunswick, Canada. - Estuar. coast. mar. Sci. 27, 445-459.

Lüning, K., 1970. Tauchuntersuchungen zur Vertikalverteilung der sublitoralen Helgoländer Algenvegetation. - Helgoländer wiss. Meeresunters. 21, 271-291.

Mitchell, R., Earll, R. C. \& Dipper, F. A., 1983. Shallow sublittoral ecosystems in the Inner Hebrides. Proc. R. Soc. Edinb. 83B, 161-194.

Petersen, C. G. J., 1913. Valuation of the sea - II. The animal communities of the sea bottom and their importance for marine zoogeography. - Rep. Dan. biol. Stn 21, 1-44.

Piepenburg, D., 1988. Zur Zusammensetzung der Bodenfauna in der westlichen Fram-Straße. - Ber. Polarforsch. 52,1-118.

Pratje, O., 1951. Die Deutung der Steingründe in der Nordsee als Endmoränen. - Dt. hydrogr. Z. 3 , 106-114.

Rachor, E., Harms, J., Heiber, W., Kröncke, I., Michaelis, H., Reise, K. \& van Bernem, K.-H., 1995. Rote Liste der bodenlebenden Wirbellosen des deutschen Wattenmeer- und Nordseebereichs. Schr.-R. Landschaftspfl. Natursch. 44, 63-74.

Rumohr, H., Brey, T. \& Ankar, S., 1987. A compilation of biometric conversion factors for benthic invertebrates of the Baltic Sea. - Publ. Baltic mar. Biol. 9, 1-56.

Salzwedel, H., 1980. Energy budgets for two populations of the bivalve Tellina fabula in the German Bight. - Veröff. Inst. Meeresforsch. Bremerh. 18, 257-287.

Salzwedel, H., Rachor, E. \& Gerdes, D., 1985. Benthic macrofauna communities in the German Bight. - Veröff. Inst. Meeresforsch. Bremerh. 20, 199-267.

Schulz, H. D., 1983. Der Steingrund bei Helgoland - Restsediment einer saalezeitlichen Endmoräne. - Meyniana 35, 45-53.

Simpson, E. H., 1949. Measurement of diversity. - Nature, Lond. 163, 688.

Stein, U., Hukriede, W. \& Rumohr, H., 1990. Historische Benthosdaten aus Nord- und Ostsee in den Jahren 1902-1912. - Mitt. zool. Mus. Kiel (Suppl.) 3, 1-189.

Stripp, K., 1969. Die Assoziationen des Benthos in der Helgoländer Bucht. - Veröff. Inst. Meeresforsch. Bremerh. 12, 95-142.

Tebble, N., 1966. British bivalve seashells. British Museum (Natural History), London, 212 pp.

Ter Braak, C. J. F., 1987. CANOCO - a FORTRAN program for canonical community ordination by \{partial\} \{detrended\} \{canonical\} correspondence analysis, principal components analysis and redundancy analysis (version 2.1 ). ITI-TNO, Wageningen, $93 \mathrm{pp}$.

Thorson, G., 1957. Bottom communities (sublittoral or shallow shelf). In: Treatise on marine ecology and palaeoecology. Ed. by J.W. Hedgpeth. Geol. Soc. Am., New York, 1, 461-534. (Mem. geol. Soc. Am. 67)

Warwick, R. M., George, C. L. \& Davies, J. R., 1978. Annual macrofauna production in a Venus community. - Estuar. coast. mar. Sci. 7, 215-241. 